\title{
Comparison of performance in metalinguistic tasks among students with and without risk of dyslexia
}

Open acess

1Professor of the Department of Speech and Hearing Therapy- FEF- Federal

Fluminense University - UFF - Nova

Friburgo (RJ), Brazil.

${ }^{2}$ Professor of the Department of Speech and Hearing Therapy and PostGraduation Program in Education at the School of Philosophy and Sciences, São Paulo State University - FFC/UNESP Marília (SP), Brazil.

Corresponding author:

claudiasilvafono@yahoo.com.br

Manuscript received: 01 January 2017 Manuscript accepted: 09 June 2017 Version of record online: 06 September 2017

\author{
Cláudia da Silva', Simone Aparecida Capellini²
}

\begin{abstract}
Introduction: Studies on students at risk for dyslexia have increased as well as the interest in verifying whether tasks involving a phonological basis can favor the performance of these students in the initial literacy process.
\end{abstract}

Objective: Evaluate the performance of students with and without risk of dyslexia in metalinguistic tasks.

Methods: Participants of this study were 40 students, aged between 5-6 years, enrolled in the 1st year of elementary school, divided into two groups, Gl: composed of 20 students without risk of dyslexia and GIl: composed of 20 students at risk of dyslexia, both groups were submitted to the Evaluation Cognitive Linguistic Skills Protocol - collective and individual version (adapted), and phonological intervention composed of tasks of relation letter/sound alphabet in sequence and in random order, rhyme, identification and manipulation of words, identification and production of syllables, syllabic segmentation and analysis, identification and phonemic segmentation, substitution, synthesis, analysis and phonemic discrimination. Results: Indicated that the students from GI and GII showed statistically superior performance in the post testing compared to the performance obtained in the pre testing.

Conclusion: The students at risk of dyslexia showed an increase in the mean of performance after the intervention, however, when compared with the performance of the students without risk for dyslexia, they presented inferior performance, indicating that, even after have underwent to the intervention, they did not reach the mean of performance of students without risk for dyslexia in metalinguistic tests.

Keywords: learning, intervention study, dyslexia, child development, literacy 


\section{INTRODUCTION}

The dyslexia is a neurobiological condition that affects the learning of reading and writing. It is characterized by slow and imprecise word recognition due to poor ability of phonological decoding, as well as, the generalization of the spelling of sounds to letter/sound correspondence and difficulties in spelling, where normally capacities such as concentration, working memory, organization and sequencing are hindered ${ }^{1,2}$.

However, there are individuals with dyslexia who have cognitive-linguistic and academic deficits in other areas, such as attention, mathematical calculus and written expression, and the ability to use suprasegmental information such as rhyme and prosody, as well as, in the generalization of the spelling of sounds to the letter/sound correspondence ${ }^{3}$.

The early identification of students at risk for dyslexia is performed with the survey of the main signs that allow the characterization of dyslexia in the preschool which are the presence of systematic and/or unsystematic exchanges, substitutions and/or omissions in speech associated with low school performance in relation to their class group ${ }^{4-7}$.

Their identification allows them to be exposed to the context of the intervention in order to minimize the characteristics of the condition and its interference in the learning of reading and writing ${ }^{4,8-10}$. As well as, offer subsidies to verify if, after the accomplishment of interventional programs with phonological approach, involving the stimulation of the cognitive-linguistic abilities, that are altered or in delay, the students show or not improvement in the school learning ${ }^{11,12}$.

Recent researches have been carried out aiming to investigate the initial process of literacy, for 1st year of elementary school students, submitted to activities with phonological base, seeking to verify its benefits in relation to educational changes and the earlier exposure of these children to formal education for literacy.

These studies also aim the early identification of students who present learning disabilities, being characterized as an initial difficulty in the formal teaching of reading and writing or for those who may have a diagnosis of dyslexia, making it possible to follow this child at school and having an indication of clinical intervention ${ }^{5,8,13}$.

Thus, the objective of this study is to evaluate the performance of students with and without risk for dyslexia in metalinguistic tasks.

\section{METHODS}

This is a comparative study, which was submitted and approved by the Committee of Ethics in Research of the School of Philosophy and Sciences of the Universidade Estadual Paulista (CEP - FFC - Unesp) under the protocol number 686/2009.

The sample consisted of 40 students from the 1 st year of elementary school, 17 girls and 23 boys, aged 5 to 6 years, divided into two groups:

Group I (GI): composed of 20 students without risk for dyslexia who underwent a phonological intervention program, $10(50 \%)$ girls $10(50 \%)$ boys.

The students, without risk of dyslexia, with good academic performance were indicated by the teachers following the criterion of satisfactory performance in two consecutive bimesters, compared to their class group. The data collection was performed at the school after staff approval, the signing of the Informed Consent Term by the parents or responsible of the students, and the definition of the schedule for the data collection by teachers.

Group II (GII): composed of 20 students at risk for dyslexia who underwent a phonological intervention program, 7 (35\%) girls and $13(65 \%)$ boys.

The students of this group were identified through the application of the Children's Language Test in the areas of phonology, vocabulary, fluency and pragmatics - $\mathrm{ABFW}^{14}$, for the identification and confirmation of the diagnosis of phonological disorder and, after confirmation from the teachers of those students who had performance under the expected, unsatisfactory performance in two consecutive bimesters, in comparison to the class group, for the predictive abilities for literacy.

The data collection began after the signing of the
Informed Consent Term by the parents or responsible of the students.

As exclusion criterion was considered the presence of sensory, motor or cognitive deficiency and as inclusion criterion was considered the signing of the Informed Consent Term, absence of auditory or visual complaint described in the school records and based on audiological and ophthalmological examination performed prior to the study, and without interventions of speech and language therapy previously to the study. And never performed intervention of speech and language therapy previously to the study.

The students were paired according to age and age group. The sample was collected by statistical indication, so that the data could offer reliability, considering an average of $3: 1$, that is, three students for each one. However, there was no sample loss and it was decided to use of the whole sample. The ratio of 3 students to a 1 (3: 1 ) is a statistical mean in the case of sample loss, so that the number of students surveyed in this sample is relevant.

The procedures used in pre and post-test were:

Cognitive-Linguistic Performance Test - collective version $^{15}$. This version was composed for subtests of recognition of the alphabet in sequence, words dictated and pseudo words and dictation of digits. Besides the subtests cited were added the subtests of recognition of the alphabet in random order and mute dictation.

Cognitive-Linguistic Performance Test - individual version $^{15}$. This version was composed for subtests of reading words and non words, rhyme, alliteration, syllabic segmentation, auditory discrimination, repetition of words and non words, numbers game inverted, rapid automatic naming pictures and rapid automatic naming of digits. This version was added the subtest rapid automatic naming of 
colors of the Rapid Automatic Naming - RAN ${ }^{16}$.

The evaluation tests used in pre and post-testing were applied in four sessions, with two sessions for pre-testing and two sessions for post-testing, lasting 50 minutes each.

The tests of the collective and individual version of the protocol were adapted to the students of this age group, since this procedure is indicated for students from 9 years old on. The adaptations were made through the selection and presentation of the tests without altering the stimuli, that is, the words of the test were not altered only the form of presenting them was modified, maintaining the reliability to the cognitive-linguistic stimuli proposed by the test.

The phonological intervention program was developed during 15 cumulative sessions that is each session presented a new activity that was worked together with the task developed in the previous session, lasting 50 minutes each, twice a week.

The steps were sequentially executed in the following order: identification of sounds and letters of the alphabet, identification of sounds and letters of the alphabet in random order, identification and production of rhyme, production of rhyme with phrases, identification and manipulation of words, identification and production of syllable, segmentation and analysis syllabic, identification and segmentation phonemic, substitution, synthesis, discrimination and analysis phonemic ${ }^{17}$.

The results were statistically analyzed using the program SPSS (Statistical Package for Social Sciences), in its version 20.0, based on the number of correct answers submitted by GI and GII, in relation to results obtained. As statistical test was used Mann-Whitney Test, in order to verify possible differences in comparing the groups studied. The level of significance adopted was $5 \%(0,05)$ for the application statistical tests.

\section{RESULTS}

In the comparison of the performance for reading ability, we can verify that there was a statistically significant difference for GII students in all subtests, in comparison to pre and post-testing, as well as for GI students, which also presented statistically significant difference in all the subtests, except for the recognition of the alphabet in sequence and for the recognition of the alphabet in random

order. The results suggest that the increase in the mean of performance for the GII students in the tests related to the reading ability occurred due to the intervention work involving the explicit teaching of the letter/sound relation, since, the increase of the average of performance in word and non word reading tests is the reflection of the alphabet recognition in sequence and in random order (Table 1).

Table 1. Distribution of the performance of students of GI and GII, in pre and post-testing, in the Reading .

\begin{tabular}{|c|c|c|c|c|c|c|c|c|c|}
\hline $\begin{array}{l}\text { Varia bles I } \\
\text { Group }\end{array}$ & & Mean & $\begin{array}{c}\text { Standard } \\
\text { deviation }\end{array}$ & Minimum & Maximum & Perc 25 & $\begin{array}{c}\text { Per } \quad 50 \\
\text { Median }\end{array}$ & Per 75 & p-value \\
\hline \multirow[t]{2}{*}{ Alf $\mathrm{Gl}$} & Pré & 26,00 & 0,00 & 26,00 & 26,00 & 26,00 & 26,00 & 26,00 & 1,000 \\
\hline & Pós & 26,00 & 0,00 & 26,00 & 26,00 & 26,00 & 26,00 & 26,00 & \\
\hline \multirow[t]{2}{*}{ Alf GII } & Pré & 23,15 & 4,60 & 7,00 & 26,00 & 22,00 & 25,50 & 26,00 & $0,005^{*}$ \\
\hline & Pós & 25,60 & 1,00 & 22,00 & 26,00 & 26,00 & 26,00 & 26,00 & \\
\hline \multirow[t]{2}{*}{ Alf Al Gl } & Pré & 25,85 & 0,67 & 23,00 & 26,00 & 26,00 & 26,00 & 26,00 & 1,000 \\
\hline & Pós & 25,85 & 0,67 & 23,00 & 26,00 & 26,00 & 26,00 & 26,00 & \\
\hline \multirow[t]{2}{*}{ Alf Al GII } & Pré & 21,40 & 5,55 & 6,00 & 26,00 & 19,25 & 22,50 & 26,00 & $0,002^{*}$ \\
\hline & Pós & 24,60 & 2,85 & 18,00 & 26,00 & 25,25 & 26,00 & 26,00 & \\
\hline \multirow[t]{2}{*}{ LP GI } & Pré & 180,75 & 108,84 & 60,00 & 493,00 & 80,25 & 165,00 & 249,00 & $0,024^{*}$ \\
\hline & Pós & 160,80 & 95,19 & 54,00 & 467,00 & 75,00 & 167,50 & 209,25 & \\
\hline \multirow[t]{2}{*}{ LP GII } & Pré & 373,45 & 398,75 & 0,00 & 1453,00 & 95,75 & 238,00 & 471,25 & $0,003^{*}$ \\
\hline & Pós & 260,35 & 239,22 & 0,00 & 866,00 & 116,75 & 189,00 & 342,50 & \\
\hline \multirow[t]{2}{*}{ LNP GI } & Pré & 56,65 & 31,05 & 0,00 & 145,00 & 32,75 & 55,00 & 74,75 & $0,005^{*}$ \\
\hline & Pós & 56,70 & 44,23 & 13,00 & 217,00 & 30,50 & 48,50 & 73,00 & \\
\hline \multirow[t]{2}{*}{ LNP GII } & Pré & 91,75 & 91,91 & 0,00 & 337,00 & 9,25 & 69,50 & 163,00 & $0,001^{*}$ \\
\hline & Pós & 73,35 & 79,72 & 0,00 & 294,00 & 7,00 & 50,50 & 121,25 & \\
\hline \multirow[t]{2}{*}{ Corm GI } & Pré & 23,15 & 11,31 & 0,00 & 40,00 & 14,75 & 24,00 & 34,25 & $0,000^{*}$ \\
\hline & Pós & 32,20 & 8,09 & 12,00 & 40,00 & 26,25 & 35,50 & 39,00 & \\
\hline \multirow[t]{2}{*}{ Corm GII } & Pré & 13,00 & 11,48 & 0,00 & 37,00 & 0,25 & 12,50 & 22,00 & $0,000^{*}$ \\
\hline & Pós & 18,95 & 10,69 & 0,00 & 40,00 & 10,00 & 20,50 & 27,00 & \\
\hline
\end{tabular}

Legend: Alf: alphabet, Alf Al: random alphabet, LP: words reading, LPN: no words reading, Corm: correct in 1(one) minute.

For the writing ability, we can verify that there was a statistically significant difference in pre and post-testing in the subtests of alphabet writing, dictation of words and no words pre and post-testing, total dictation pre and post- testing and mute dictation pre and post-testing. The data suggest that the learning of the letter/sound relationship, through the intervention program, was favorable for the performance in relation to the coding of words and not 
words, since this type of intervention assists the generative mechanism of phonological memory used in writing processes (Table 2).
When comparing the results of the phonological awareness ability, we can verify that there was a statistically significant difference for subtests of alliteration, rhyme and

Table 2. Distribution of the performance of students of $\mathrm{GI}$ and GII, in pre and post-testing, in the Writing Ability.

\begin{tabular}{|c|c|c|c|c|c|c|c|c|c|}
\hline $\begin{array}{l}\text { Variables I } \\
\text { Group }\end{array}$ & & Mean & $\begin{array}{c}\text { Stand ard } \\
\text { deviation }\end{array}$ & Minimum & Maximum & Perc 25 & $\begin{array}{c}\text { Per } 50 \text { Me- } \\
\text { dian }\end{array}$ & Per 75 & $p$-value \\
\hline \multirow[t]{2}{*}{ E Alf GI } & Pré & 25,85 & 0,49 & 24,00 & 26,00 & 26,00 & 26,00 & 26,00 & 0,180 \\
\hline & Pós & 26,00 & 0,00 & 26,00 & 26,00 & 26,00 & 26,00 & 26,00 & \\
\hline \multirow[t]{2}{*}{ E Alf GII } & Pré & 20,75 & 6,46 & 7,00 & 26,00 & 15,50 & 24,50 & 26,00 & $0,001^{*}$ \\
\hline & Pós & 24,20 & 3,58 & 12,00 & 26,00 & 23,50 & 26,00 & 26,00 & \\
\hline \multirow[t]{2}{*}{ DP GI } & Pré & 17,75 & 4,51 & 8,00 & 26,00 & 16,25 & 18,50 & 20,00 & $0,000^{*}$ \\
\hline & Pós & 27,50 & 3,76 & 16,00 & 30,00 & 26,00 & 29,00 & 30,00 & \\
\hline \multirow[t]{2}{*}{ DP GII } & Pré & 12,65 & 9,19 & 0,00 & 28,00 & 1,75 & 14,50 & 19,75 & $0,000^{*}$ \\
\hline & Pós & 20,25 & 9,17 & 0,00 & 30,00 & 16,00 & 24,00 & 27,00 & \\
\hline \multirow[t]{2}{*}{ DNP GI } & Pré & 5,15 & 1,76 & 2,00 & 9,00 & 3,25 & 5,00 & 6,00 & $0,000^{*}$ \\
\hline & Pós & 7,55 & 1,23 & 5,00 & 9,00 & 7,00 & 7,50 & 9,00 & \\
\hline \multirow[t]{2}{*}{ DNP GII } & Pré & 2,30 & 2,39 & 0,00 & 7,00 & 0,00 & 1,50 & 5,00 & $0,001^{*}$ \\
\hline & Pós & 3,90 & 2,17 & 0,00 & 7,00 & 2,00 & 4,50 & 5,75 & \\
\hline \multirow[t]{2}{*}{ DT GI } & Pré & 30,70 & 5,12 & 23,00 & 39,00 & 25,50 & 32,50 & 35,00 & $0,002^{*}$ \\
\hline & Pós & 35,05 & 4,63 & 21,00 & 39,00 & 32,00 & 37,00 & 38,00 & \\
\hline \multirow[t]{2}{*}{ DT GII } & Pré & 14,95 & 10,66 & 0,00 & 33,00 & 2,25 & 17,00 & 24,00 & $0,000^{*}$ \\
\hline & Pós & 24,15 & 11,14 & 0,00 & 36,00 & 18,50 & 28,00 & 32,75 & \\
\hline \multirow[t]{2}{*}{ DM GI } & Pré & 16,95 & 1,99 & 13,00 & 20,00 & 16,00 & 17,00 & 18,75 & $0,002^{*}$ \\
\hline & Pós & 18,50 & 1,64 & 15,00 & 20,00 & 18,00 & 19,00 & 20,00 & \\
\hline \multirow[t]{2}{*}{ DM GII } & Pré & 5,90 & 4,90 & 0,00 & 14,00 & 0,50 & 5,50 & 10,50 & $0,000^{*}$ \\
\hline & Pós & 9,10 & 4,86 & 0,00 & 16,00 & 5,50 & 8,50 & 13,75 & \\
\hline
\end{tabular}

Legend: E Alf: writing the alphabet, DP: words dictation, DNP: no words dictation, DM: mute dictation.

syllabic segmentation in pre and post-testing, for both groups, suggesting that the interventional work with phonological abilities reflected in the perception of larger sound segments, such as syllables and word endings, and in the perception of smaller segments such as phonemes (Table 3 ).

In the comparison of pre and post-testing for auditory processing ability, it was possible to verify statistically significant difference in subtests of discrimination of sounds, repetition of words and non words, dictation of numbers and inverted numbers, for the pre and post-testing, of the GI and GII groups, indicating that there was an improvement in performance in relation to sound perception, for the storage and retrieval of information for words and digits, in both groups (Table 4).

Table 3. Distribution of the performance of students of GI and GII, in pre and post-testing, in the Phonological Awareness Ability.

\begin{tabular}{|c|c|c|c|c|c|c|c|c|c|}
\hline $\begin{array}{l}\text { V a ri a b I e s I } \\
\text { Group }\end{array}$ & & Mean & $\begin{array}{l}\text { Standard de- } \\
\text { viation }\end{array}$ & Minimum & Maximum & Perc 25 & $\begin{array}{l}\text { Per } 50 \text { Me- } \\
\text { dian }\end{array}$ & Per 75 & $p$-value \\
\hline \multirow[t]{2}{*}{ Alit GI } & Pré & 18,20 & 1,61 & 15,00 & 20,00 & 17,00 & 18,50 & 19,75 & $0,001^{*}$ \\
\hline & Pós & 19,90 & 0,45 & 18,00 & 20,00 & 20,00 & 20,00 & 20,00 & \\
\hline \multirow[t]{2}{*}{ Alit GII } & Pré & 12,85 & 4,78 & 0,00 & 20,00 & 10,25 & 12,50 & 17,00 & $0,000^{*}$ \\
\hline & Pós & 17,45 & 2,19 & 13,00 & 20,00 & 16,00 & 17,50 & 19,75 & \\
\hline \multirow[t]{2}{*}{ Rhyme GI } & Pré & 17,25 & 2,29 & 12,00 & 20,00 & 16,25 & 18,00 & 19,00 & $0,000^{*}$ \\
\hline & Pós & 19,85 & 0,49 & 18,00 & 20,00 & 20,00 & 20,00 & 20,00 & \\
\hline \multirow[t]{2}{*}{ Rhyme Gll } & Pré & 11,05 & 3,93 & 3,00 & 17,00 & 8,25 & 11,00 & 14,00 & $0,000^{*}$ \\
\hline & Pós & 17,40 & 2,04 & 11,00 & 20,00 & 17,00 & 17,50 & 18,75 & \\
\hline \multirow[t]{2}{*}{ SS GI } & Pré & 8,70 & 1,49 & 4,00 & 10,00 & 8,00 & 9,00 & 10,00 & $0,001^{*}$ \\
\hline & Pós & 10,00 & 0,00 & 10,00 & 10,00 & 10,00 & 10,00 & 10,00 & \\
\hline \multirow[t]{2}{*}{ SS GII } & Pré & 8,45 & 1,93 & 3,00 & 10,00 & 8,00 & 9,00 & 10,00 & $0,003^{*}$ \\
\hline & Pós & 9,65 & 0,67 & 8,00 & 10,00 & 9,25 & 10,00 & 10,00 & \\
\hline
\end{tabular}


In the comparison of the pre and post-testing groups, in relation to the ability of processing speed, there was statistically significant difference for the subtests of rapid naming of figures, first and second rapid naming of numbers and rapid naming of colors for GI, differently from GII that presented statistically significant result only for the rapid naming of colors. Suggesting improved processing, access and retrieval of visual information for GI and performance maintenance, without influences from the phonological intervention program for GII (Table 5).

Table 4. Distribution of the performance of students of GI and GII, in pre and post-testing, in the Auditory Processement Ability

\begin{tabular}{|c|c|c|c|c|c|c|c|c|c|}
\hline $\begin{array}{l}\text { Variables } \\
\text { Group }\end{array}$ & I & Mean & $\begin{array}{l}\text { Standard } \\
\text { deviation }\end{array}$ & Minimum & Maximum & Perc 25 & $\begin{array}{l}\text { Per } 50 \text { Me- } \\
\text { dian }\end{array}$ & Per 75 & p-value \\
\hline \multirow[t]{2}{*}{ DS GI } & Pré & 17,40 & 3,78 & 5,00 & 20,00 & 17,00 & 19,00 & 20,00 & $0,001^{*}$ \\
\hline & Pós & 19,55 & 1,15 & 16,00 & 20,00 & 20,00 & 20,00 & 20,00 & \\
\hline \multirow[t]{2}{*}{ DS GII } & Pré & 13,80 & 2,53 & 9,00 & 19,00 & 12,00 & 14,00 & 15,75 & $0,000^{*}$ \\
\hline & Pós & 17,65 & 2,56 & 11,00 & 20,00 & 17,00 & 18,00 & 19,00 & \\
\hline \multirow[t]{2}{*}{ RP GI } & Pré & 4,95 & 0,95 & 3,00 & 6,00 & 4,25 & 5,00 & 6,00 & $0,017^{*}$ \\
\hline & Pós & 5,55 & 0,51 & 5,00 & 6,00 & 5,00 & 6,00 & 6,00 & \\
\hline \multirow[t]{2}{*}{ RP GII } & Pré & 3,20 & 1,20 & 2,00 & 6,00 & 2,00 & 3,00 & 4,00 & $0,001^{*}$ \\
\hline & Pós & 4,75 & 0,91 & 3,00 & 6,00 & 4,00 & 5,00 & 5,00 & \\
\hline \multirow[t]{2}{*}{ RNP GI } & Pré & 2,30 & 0,73 & 1,00 & 4,00 & 2,00 & 2,00 & 2,75 & 0,366 \\
\hline & Pós & 2,45 & 0,61 & 2,00 & 4,00 & 2,00 & 2,00 & 3,00 & \\
\hline \multirow[t]{2}{*}{ RNP GII } & Pré & 2,40 & 0,68 & 2,00 & 4,00 & 2,00 & 2,00 & 3,00 & $0,005^{*}$ \\
\hline & Pós & 2,80 & 0,62 & 2,00 & 4,00 & 2,00 & 3,00 & 3,00 & \\
\hline \multirow[t]{2}{*}{ N GI } & Pré & 73,25 & 19,30 & 44,00 & 116,00 & 58,75 & 70,50 & 83,50 & $0,021^{*}$ \\
\hline & Pós & 65,45 & 14,38 & 43,00 & 99,00 & 56,50 & 63,00 & 75,25 & \\
\hline \multirow[t]{2}{*}{ N GII } & Pré & 83,75 & 22,30 & 49,00 & 117,00 & 60,25 & 86,50 & 106,50 & $0,000^{*}$ \\
\hline & Pós & 64,85 & 13,43 & 43,00 & 93,00 & 56,00 & 63,00 & 74,25 & \\
\hline \multirow[t]{2}{*}{ NI GI } & Pré & 3,35 & 1,46 & 0,00 & 6,00 & 2,00 & 3,00 & 4,75 & $0,006^{*}$ \\
\hline & Pós & 4,05 & 1,23 & 2,00 & 6,00 & 3,00 & 4,00 & 5,00 & \\
\hline \multirow[t]{2}{*}{ NI GII } & Pré & 3,45 & 1,28 & 0,00 & 6,00 & 3,00 & 3,50 & 4,00 & $0,001^{*}$ \\
\hline & Pós & 4,40 & 1,00 & 2,00 & 6,00 & 4,00 & 4,50 & 5,00 & \\
\hline
\end{tabular}

Legend: DS: sound discrimination, RP: words repetition, RNP: no words repetition, N: numbers, NI: invert numbers.

Table 5. Distribution of students performance of GI and GII, in pre and post-testing, in the Speed Processement Ability.

\begin{tabular}{|c|c|c|c|c|c|c|c|c|c|}
\hline Variables/Group & & Mean & $\begin{array}{l}\text { St and a rd } \\
\text { deviation }\end{array}$ & Minimum & Maximum & Perc 25 & $\begin{array}{l}\text { Per } 50 \text { Me- } \\
\text { dian }\end{array}$ & Per 75 & $p$-value \\
\hline \multirow[t]{2}{*}{ NRF GI } & Pré & 43,30 & 7,28 & 32,00 & 58,00 & 38,25 & 43,00 & 46,00 & $0,004^{*}$ \\
\hline & Pós & 38,10 & 5,97 & 23,00 & 49,00 & 34,00 & 38,50 & 42,75 & \\
\hline \multirow[t]{2}{*}{ NRF GII } & Pré & 50,05 & 7,08 & 40,00 & 64,00 & 44,00 & 49,00 & 56,00 & 0,056 \\
\hline & Pós & 47,20 & 6,34 & 34,00 & 58,00 & 42,00 & 48,00 & 51,75 & \\
\hline \multirow[t]{2}{*}{ NRN1 GI } & Pré & 43,30 & 8,26 & 32,00 & 63,00 & 37,00 & 41,50 & 49,00 & $0,002^{*}$ \\
\hline & Pós & 39,05 & 6,00 & 29,00 & 49,00 & 34,25 & 38,00 & 45,50 & \\
\hline \multirow[t]{2}{*}{ NRN1 GII } & Pré & 54,65 & 17,68 & 0,00 & 83,00 & 49,75 & 55,50 & 65,00 & 0,211 \\
\hline & Pós & 54,30 & 13,25 & 35,00 & 95,00 & 45,75 & 51,50 & 61,75 & \\
\hline \multirow[t]{2}{*}{ NRN2 GI } & Pré & 43,45 & 7,63 & 31,00 & 64,00 & 38,75 & 41,50 & 47,00 & $0,003^{*}$ \\
\hline & Pós & 38,30 & 3,91 & 34,00 & 47,00 & 35,25 & 37,00 & 40,50 & \\
\hline \multirow[t]{2}{*}{ NRN2 GII } & Pré & 53,65 & 17,84 & 0,00 & 83,00 & 46,00 & 57,00 & 64,50 & 0,096 \\
\hline & Pós & 53,95 & 11,77 & 35,00 & 87,00 & 47,25 & 55,00 & 58,00 & \\
\hline \multirow[t]{2}{*}{ NRC GI } & Pré & 73,25 & 19,30 & 44,00 & 116,00 & 58,75 & 70,50 & 83,50 & $0,009^{*}$ \\
\hline & Pós & 65,45 & 14,38 & 43,00 & 99,00 & 56,50 & 63,00 & 75,25 & \\
\hline \multirow[t]{2}{*}{ NRC GII } & Pré & 83,75 & 22,30 & 49,00 & 117,00 & 60,25 & 86,50 & 106,50 & $0,001^{*}$ \\
\hline & Pós & 64,85 & 13,43 & 43,00 & 93,00 & 56,00 & 63,00 & 74,25 & \\
\hline
\end{tabular}

Legend: NRF: rapid naming of figures, NRN1: rapid naming of numbers/first, NRN2: rapid naming of numbers/second, NRC: rapid naming of colors. 


\section{DISCUSSION}

In the comparison of the performance of GI and GII, for the reading ability, the students of GII obtained superior performance in the subtests of Recognition of the Alphabet and Recognition of the Random Alphabet associated with sounds, after the application of the intervention program, indicating that the work involving the letter/sound relationship and the phonological abilities favored the performance of these students regarding the sound perception (phoneme) and its corresponding graphic (letter). For the tests related to reading words, not words and correct in one minute, was observed decrease in average performance for reading words and not words with increased performance averages for the number of words read correctly in one minute, which suggests to the interference of the decoding and the access to the phonological memory, formed during the intervention, making the reading more laborious, fast and assertive $e^{6,11}$.

For writing ability, the superior performance in posttesting compared to pre-testing, to students of GII, indicates that the effects of phonological awareness when worked on in the initial series of the literacy, through letter/sound association, allows access to phonological memory for word formation, which can be retrieved during writing. Thus, students with phonological deficits, such as those observed in students of GII, when inserted in interventional programs with instruction in phonological aspects tend to overcome errors that were previously unnoticeable for this type of population, but which will reflect, in the future, the acquisition of writing, since the development of phonological awareness helps in the process of coding words and not words, positively interfering with the access to phonological route (for the formation of new words) and the lexical route (for access to words already belonging to the vocabulary of the child) $)^{7,15,18}$.

In the subtests of Rhyme, Alliteration and Syllabic Segmentation there was an increase in the mean performance for the GI and GII groups, from the work performed with the phonological intervention program. However, we can verify that the increase in the average performance for the correct answers of the students of the GII was lower than the average reached by the students of the GI.

Such performance may be justified by the fact that the difficulties of students at risk for dyslexia, belonging to the GII group, to perform this type of test suggest a deficit in phonological representation, that is, a disorganization in the access to the phonological processing of the information or even the little ability to manipulate the representations in the superior cognitive level, originating from the diagnosis of phonological disorder and characteristic of individuals with dyslexia ${ }^{9,10,19}$. Thus, the type of stimulus offered during the intervention was efficient to increase the mean of performance in specific activities of phonological awareness related to learning, but they were not sufficient to reach the performance of the students without risk for dyslexia ${ }^{20,21}$

For the auditory processing ability, in the comparison of the pre and post-testing, the students of the GII group presented statistically significant performance for all evaluated subtests.

Recent studies indicate that the work with phonological awareness exerts influence in abilities that involve the discrimination of the acoustic signals (phonemes), also helping, in the retention of the information in the phonological memory ${ }^{6,13,20,22}$. Thus, activities involving the repetition of words and not words, and the repetition of sequences, be they digits or figures, involve directly the processing auditory and/or visual of information, retention and retrieval of stored information for stimulus reproduction requested ${ }^{8,10,23-25}$.

Thus, for the GII group, composed of students at risk for dyslexia, the difficulty in discriminating auditory stimuli and in processing auditory information may be more compromised, due to a characteristic of the phonological disorder ${ }^{26}$. However, when working on the discrimination of sounds in the early stages of literacy, the difficulty in distinguishing and storing information for future use in reading tasks, for example, becomes more effective, because phonological work memory will be able to temporarily retain and manipulate information while participating in other specific cognitive tasks, favoring performance in oral comprehension, as can be observed in students of the $\mathrm{GI}^{24,25}$.

In the comparison of pre and post-testing for the Processing Speed Ability, the results indicate statistically significant difference for the subtests of Rapid Naming of Figures, Numbers and colors for students of GI, with statistically significant difference for students of GII, only for subtest of rapid naming of colors. The decrease of the means of performance is a positive factor, because these tests are evaluated by the time necessary for the execution of the test. This indicates a better performance average for students in the GI group, possibly due to the intervention done. In contrast, the maintenance of performance averages for students in the GII group suggests a difficulty in processing visual stimuli, which may be due to a change in the visual processing of the information, which is a difficulty found in children with dyslexia, which could justify the performance of this group $^{6,10,21-23}$.

The literature also indicates that the performance of students at risk for dyslexia belonging to the GII group can be explained due to the change in access to information, related to a phonological based disorder characteristic of the diagnosis of phonological disorder, suggesting the overload of phonological memory generated by the deficit in the phonological processing of the information and, consequently, the necessity for more time to perform decoding can be transferred to more complex activities such as reading and writing.

In conclusion, students at risk for dyslexia showed higher performance averages after exposure to intervention involving metalinguistic tasks, which afforded the development of skills of reading, writing, phonological awareness, processing speed and auditory processing.

However, when compared with the performance of students without risk for dyslexia, it was possible to verify that students at risk for dyslexia were underperformance, indicating, even after, underwent to the intervention they did not reach the averages of performance of students without risk for dyslexia in metalinguistic tests.

\section{Acknowledgements}

The National Council for Scientific and Technological Development $(\mathrm{CNPq})$ for supporting the research. 


\section{REFERENCES}

1. Boets B, Wounters J, van Wieringen A, Ghesquiére P. Auditory processing, speech perception and phonological ability in pre-school children at high-risk for dyslexia: a longitudinal study of the auditory temporal processing theory. Neuropsychologia. 2007;45(8):1608-20. DOI: http://dx.doi.org/10.1016/j.neuropsychologia.2007.01.009

2. Raschle MN, Zuk J, Gaab N. Functional characteristics of developmental dyslexia in left-hemispheric posterior brain regions predate reading onset. Proc Natl Acad Sci U S A. 2012;109(6):2156-61. DOI: https://dx.doi.org/10.1073/pnas.1107721109

3. Machado AC, Capellini SA. Caracterização do desempenho de crianças com dislexia do desenvolvimento em tarefas de escrita. Rev Bras Cresc Desenv Hum. 2011;21(1):133-9. DOI: http://dx.doi.org/10.7322/jhgd.20002

4. Fletcher JM, Vaughn S. Response to intervention: Preventing and remediating academic difficulties. Child Dev Perspectiv. 2009;3(1):30-7. DOI: https://dx.doi.org/10.1111/j.1750-8606.2008.00072.x

5. Savill NJ, Thierry G. Reading for sound with dyslexia: Evidence for early orthographic and late phonological integration deficits. Brain Res. 2011;1385:192-205.

DOI: https://dx.doi.org/10.1016/j.brainres.2011.02.012

6. Fukuda MTM, Capellini, SA. Programa de intervenção fonológica associado à correspondência grafema-fonema em escolares de risco para a dislexia. Psicol Reflex Crít. 2012;25(4):783-90. DOI: http://dx.doi.org/10.1590/S0102-79722012000400018

7. Wang LC, Yang HM, Tasi HJ, Chan SY. Learner-generated drawing for phonological and orthographic dyslexic readers. Res Dev Disabil. 2013;34(1):228-33. DOI: http://dx.doi.org/10.1016/j.ridd.2012.08.006

8. Macoir J, Fossard M, Saint-Pierre MC, Auclair-Ouellet N. Phonological or procedural dyslexia: Specific deficit of complex grapheme-to-phoneme conversion. J Neurolinguist. 2012;25(3):163-77. DOI: http://dx.doi.org/10.1016/j.jneuroling.2011.11.002

9. Lonigan CJ, Purpura DJ, Wilson SB, Walker PM, Clancy-Menchetti. Evaluating the components of an emergent literacy intervention for preschool children at risk for reading difficulties. J Exp Child Psychol. 2013;114(1):111-30. DOI: http://dx.doi.org/10.1016/j.jecp.2012.08.010

10. Toll AWM, van Luit JEW. Accelerating the early numeracy development of kindergartners with limited working memory skills through remedial education. Res Dev Disabil. 2013;34(2):745-55. DOI: http://dx.doi.org/10.1016/j.ridd.2012.09.003

11. Monteiro SM, Soares M. Processos cognitivos na leitura inicial: relação entre estratégias de reconhecimento de palavras e alfabetização. Educ Pesqui. 2014;40(2):449-66. DOI:http://dx.doi.org/10.1590/S1517-97022014005000006

12. Cunningham A, Carroll J. Age and schooling effects on early and phoneme awareness. J Exp Child Psychol. 2011;109:248-55. DOI: http://dx.doi.org/10.1016/j.jecp.2010.12.005

13. Ortiz R, Estévez A, Umnetón M, Domínguez C. Visual and auditory perception in preschool children at risk for dyslexia. Res Dev Disabil. 2014;35(11):2673-80. DOI: http://dx.doi.org/10.1016/j.ridd.2014.07.007

14. Andrade CRF, Befi-Lopes DM, Fernandes FDM, Wertzner HF. ABFW: teste de linguagem infantil nas áreas de fonologia, vocabulário, fluência e pragmática. Carapicuiba: Pró- Fono; 2004.

15. Capellini SA, Smythe I, Silva C. Protocolo de avaliação de habilidades cognitivo-linguísticas. Livro do profissional e do professor. Marília: Fundepe; 2012.

16. Denckla MB, Rudel R. Rapid "automatized" naming of pictured objects, colors, letters and numbers by normal children. Cortex. 1974;10(2):186-202. DOI: http://dx.doi.org/10.1016/S0010-9452(74)80009-2

17. Silva C, Capellini SA. Eficácia de um programa de intervenção fonológica com escolares de risco para a dislexia. Rev Cefac. 2015; 17(6):1827-37. DOI: http://dx.doi.org/10.1590/1982-021620151760215

18. Sarver DE, Rapport MD, Kofler MJ, Scanlan SW, Raiker JS, Altro TA, et al. Attention problems, phonological short-term memory, and visuospatial short-term memory: Differential effects on near-and long-term scholastic achievement. Learn Individ Differ. 2012;22(1):8-19. DOI: http://dx.doi.org/10.1016/j.lindif.2011.09.010

19. Ferrante C, Borsel JV, Pereira MMB. Análise dos processos fonológicos em crianças com desenvolvimento fonológico normal. Rev Soc Bras Fonoaudiol. 2009;14(1):36-40. DOI: http://dx.doi.org/10.1590/S1516-80342009000100008

20. Swanson HL, Kehler P, Jerman O. Working memory, strategy knowledge, and strategy instruction in children with reading disabilities. J Learn Disabil. 2010;41(1):24-47. DOI: http://dx.doi.org/10.1177/0022219409338743

21. Brito CLR, Uzêda CPQ, Vieira JG, Cavalheiro LG. Habilidades de letramento após intervenção fonoaudiológica em crianças do $1^{\circ}$ ano do ensino fundamental. Rev Soc Bras Fonoaudiol. 2010;15(1):88-95. DOI: http://dx.doi.org/10.1590/S1516-80342010000100015 
22. Furnes B, Samuelsson S. Phonological awareness and rapid automatized naming predicting early development in reading and spelling: Results from a cross-linguistic longitudinal study. Learn Individ Differ. 2011;21(1):85-95. DOI: http://dx.doi.org/10.1016/j.lindif.2010.10.005

23. Buján $A$, Lindín $M$, Díaz $F$. The effect of aging on movement related cortical potentials during a face naming task. Int J Psychophysiol. 2010;78(2):169-78. DOI: http://dx.doi.org/10.1016/j.jpsycho.2010.07.006

24. Piai V, Roelofs A, Schriefers $H$. Semantic interference in immediate and delayed naming and reading: Attention and task decisions. J Mem Lang. 2011;64(4):404-23. DOI: http://dx.doi.org/10.1016/j.jml.2011.01.004

25. Jones MW, Branigan HP, Hatzidaki A, Obregón M. Is the naming deficit in dyslexia a misnomer? Cognition. 2010;116(1):56-70. DOI: http://dx.doi.org/10.1016/j.cognition.2010.03.015

26. Tenório SMPCP, Ávila CRB. Processamento fonológico e desempenho escolar nas séries iniciais do ensino fundamental. Rev CEFAC. 2012;14(1):30-8. DOI: http://dx.doi.org/10.1590/S1516-18462011005000099

\section{Resumo}

Introdução: Estudos sobre escolares de risco para a dislexia tem se tornado cada vez mais frequentes, assim como, o interesse em verificar se as tarefas envolvendo uma base fonológica podem favorecer o desempenho desses escolares em processo inicial de alfabetização.

Objetivo: Avaliar o desempenho de escolares com e sem risco para a dislexia em tarefas metalinguísticas.

Método: Participaram deste estudo 40 escolares, com idade entre 5 a 6 anos, matriculados no $1^{\circ}$ ano do ensino fundamental, divididos em dois grupos, GI: composto por 20 escolares sem risco para dislexia e GII: composto por 20 escolares de risco para a dislexia, ambos os grupos foram submetidos ao Protocolo de Avaliação das Habilidades Cognitivo-Liguísticas nas versões coletiva e individual (adaptado), e a intervenção fonológica composta por tarefas de relação letra/som do alfabeto em sequência e em ordem aleatória, rima, identificação e manipulação de palavras, identificação e produção de sílabas, segmentação e análise silábica, identificação e segmentação fonêmica, substituição, síntese, análise e discriminação fonêmica.

Resultados: Indicaram que os escolares do GI e Gll apresentaram desempenho estatisticamente superior na pós-testagem comparado ao desempenho obtido na pré-testagem.

Conclusão: Os escolares de risco para a dislexia apresentaram aumento das médias de desempenho após a intervenção, no entanto, ao ser comparado com o desempenho dos escolares sem risco para a dislexia, apresentaram desempenho inferior, indicando que, mesmo após, submetidos à intervenção, não alcançaram as médias de desempenho dos escolares sem risco para a dislexia em provas metalinguísticas.

Palavras-chave: aprendizagem, estudos de intervenção, dislexia, desenvolvimento infantil, alfabetização

${ }^{0}$ The authors (2017), thiis article is distributed under the terms of the Creative Commons Attribution 4.0 International License (http://creativecommons.org/licenses/by/4.0/), which permits unrestricted use, distribution, and reproduction in any medium, provided you give appropriate credit to the original author(s) and the source, provide a link to the Creative Commons license, and indicate if changes were made. The Creative Commons Public Domain Dedication waiver (http://creativecommons.org/ publicdomain/zero/1.0/) applies to the data made available in this article, unless otherwise stated. 